\title{
Efficacy of Biorational Compounds against Mustard Aphid (Lipaphis erysimi Kalt.) and English Grain Aphid (Sitobion avenae Fab.) under Laboratory Conditions in Nepal
}

\author{
Dipak Khanal $(\mathbb{D}),{ }^{1}$ Salu Maharjan $\left(\mathbb{D},{ }^{2}\right.$ Jamuna Lamichhane ${ }^{D},{ }^{1}$ Pritika Neupane, ${ }^{1}$ \\ Srijana Sharma $\mathbb{D}^{2},{ }^{2}$ and Pushpa Pandey $\mathbb{1}^{1}$ \\ ${ }^{1}$ Institute of Agriculture and Animal Science, Tribhuvan University, Kirtipur, Nepal \\ ${ }^{2}$ Agriculture and Forestry University, Chitwan, Nepal \\ Correspondence should be addressed to Dipak Khanal; dipakbabu@hotmail.com
}

Received 20 July 2019; Revised 26 November 2019; Accepted 6 December 2019; Published 29 February 2020

Academic Editor: Xianzhang Wang

Copyright (C) 2020 Dipak Khanal et al. This is an open access article distributed under the Creative Commons Attribution License, which permits unrestricted use, distribution, and reproduction in any medium, provided the original work is properly cited.

\begin{abstract}
Mustard aphid (Lipaphis erysimi) and English grain aphid (Sitobion avenae) are among the most important pests in mustard and wheat fields in Nepal. Biocide Manic (Metarhizium anisopliae a.i. $=1 \times 10^{9}$ spores $/ \mathrm{ml}$ ) at $3 \mathrm{ml} / 1$ water, Agri Sakti (Beauveria bassiana a.i. $=1 \times 10^{9}$ spores $/ \mathrm{ml}$ ) at $3.3 \mathrm{ml} / 1$ water, Varunastra (Verticillium lecanii spores $2 \%$ aqueous suspension, $2 \times 10^{8} \mathrm{CFU} /$ $\mathrm{ml}$ ) at $6 \mathrm{ml} / \mathrm{l}$ water, Mahastra (Bacillus thuringiensis var. kurstaki $0.5 \%$ wettable powder) at $6 \mathrm{~g} / \mathrm{l}$ water, Neemraj Super (Azadirachitin $0.3 \% \mathrm{w} / \mathrm{w}$ ) at $3.3 \mathrm{ml} / \mathrm{l}$ water, Tracer (Spinosad $90 \%$ spinosyns) at $0.33 \mathrm{ml} / \mathrm{l}$ water, and control treatment (pure water) were used to test their efficacy against L. erysimi and S. avenae, using leaf dip and spray methods under laboratory conditions in Rupandehi, Nepal, in the year 2018. Each treatment was replicated four times, and the experiment was carried out in a randomized complete block design. Mortality of aphids was recorded at 24, 48, 72, and 98 hours after treatment application. The result revealed highest mortality of mustard aphids with Agri Sakti at 24 hours after treatment (HAT); however, Neemraj Super was found to be the most effective at 48, 72, and 96 HAT with the leaf spray method. With the leaf dip method, Neemraj Super killed more mustard aphids than other treatments at all observed time points. Among tested biorational products, Agri Sakti was found to be most effective against English grain aphids in both leaf spray and leaf dip methods. In all the bioassays, the mortality caused by biorational compounds over control was highly significant. The present study suggests for further verification of the biorational products in the field and development of novel management strategies against different species of aphids.
\end{abstract}

\section{Introduction}

Rapeseed mustard (Brassica campestris L. var tori; family: Brassicaceae) is an important oilseed crop in Nepal [1]. Among the oilseed crops grown, rapeseed has the highest share of acreage, i.e., $85 \%$ [2], and provides about $80 \%$ of the vegetable oil need in Nepalese diet [3]. 159,710 mt of mustard is grown on 160,405 ha, with a productivity of $0.99 \mathrm{mt} / \mathrm{ha}$ [4]. This productivity is lower compared to that of other countries [5]. Among many factors responsible for the low yield, insect pests play a key role. Rapeseed mustard is attacked by more than 43 species of insect pests [6], with Mustard aphid, Lipaphis erysimi (Kalt.), being the key pest species in Nepal $[7,8]$. L. erysimi can result in approximately $35-75 \%$ reduction in yield $[9,10]$ or a $6-87 \%$ reduction in the oil content $[11,12]$. Large mustard aphid colonies cause deformations of twigs and tender parts of the plant and curling of the leaves. The infested parts shrivel and finally turn yellow [13]. Aphids are mainly found on the undersides of leaves and prefer young leaves and inflorescences [14]. Apart from the primary damage caused by feeding, aphids also secrete honeydew, which serves as a medium for sooty mould development, further obstructing photosynthesis [15]. Aphids are also responsible for the transmission of viruses such as the turnip mosaic virus [16]. 
Wheat (Triticum aestivum L.; family: Graminae) is the third most important cereal in Nepal after rice and maize. A previous study reported that $1,879,191 \mathrm{mt}$ of wheat is produced on 735,850 ha of land in Nepal, with a productivity of $2.55 \mathrm{mton} / \mathrm{ha}$ [4]. Wheat is affected by various insect pests like aphids, armyworms, sting bugs, wheat midge, and Hessian flies. The English grain aphid Sitobion avenae (Fab.) is a very common pest of cultivated cereals grown throughout the world [17]. They colonise the leaves and stalks of young developing plants. When heading begins, they migrate to the ear and develop in the bracts and kernels. They suck the phloem sap and inject toxic saliva into the plant tissues [18]. The saliva causes galling, rolling, and deformation of leaves. The rolled leaves trap the reproductive parts of the plants, reducing pollination and fertilisation [19]. Upon heavy infestation, a reduced number of well-developed grains are formed, which reduces yield [20]. The aphids also transmit destructive viruses such as barley yellow dwarf virus [21]. Yield loss due to aphid infestation may reach $30-60 \%$ [22].

Chemical insecticides have often been used irrationally and haphazardly without regard to human health and environmental damage [23]. Their repeated use has increased pest resistance $[24,25]$, pest resurgence, and secondary pest outbreaks [26] and increased the pesticide residue levels in the harvested products [27]. Excessive use of chemical insecticides is also responsible for the pollution of soil and air [28], along with harmful effects on nontarget organisms, including pollinators [29], ultimately putting a risk to the balance of nature and human health [30]. Therefore, sustainable strategies are needed for the management of aphids.

Microorganisms are active ingredients in biopesticides [31]. Entomopathogenic fungi are mostly host-specific and pose minimal risk to the environment and mammals [32]. Beauveria bassiana (Bals. Criv.) causes white muscardine and Metarhizium anisopliae (Metsch.) causes green muscardine disease in target insects $[33,34]$. Use of Verticillium lecanii (Z.) is suggested as a complementary biological control strategy in an integrated pest management (IPM) program against aphids [35]. The rodshape, spore-forming, Gram-positive entomopathogenic bacterium Bacillus thuringiensis Berliner can produce a crystal protein [36]. Azadirachtin is the main pesticidal component of neem extracts, which has feeding-deterrent, repellent, toxic, and growth disruption properties against aphids [37]. These biopesticides are commercially available in different formulations and under different brand names [38]. They are environmentally friendly, safe, and have no residual effects [39]. This investigation was carried out to evaluate the efficacy of biorational compounds and chemical insecticide against mustard and English grain aphids under laboratory conditions in Rupandehi, Nepal.

\section{Methodology}

The research was conducted at the Entomology Laboratory of the Institute of Agriculture and Animal Science
(IAAS), Paklihawa Campus, Nepal. The experiment was carried out from February 10, 2018, to March 8, 2018, with an average temperature of $22.5^{\circ} \mathrm{C}\left(18^{\circ} \mathrm{C}-25^{\circ} \mathrm{C}\right)$ and a relative humidity of $80 \%$ during the research period. Healthy and unaffected mustard and wheat plants were collected from fields of the IAAS farm and transplanted into two separate pots, respectively. The pots were then covered with nylon net mesh. Two-hundred mustard aphids and 200 English grain aphids were collected from mustard and wheat fields, respectively, and released into the respective pots covered with nylon mesh. After three days, the old adult aphids were removed and the newly emerged adults were used in further laboratory studies.

2.1. Materials. The compounds used in the study are listed in Table 1 . They were prepared as follows:

(i) Biocide Manic, manufactured by Agricare Nepal Pvt. Ltd., available in liquid form, was prepared at a concentration of $3 \mathrm{ml} / 1000 \mathrm{ml}$ water. Five grams sugar was added to provide nutrient to the fungus, and 3 drops of Tween- 80 were added to homogenize the suspension.

(ii) Agri Sakti, manufactured by Agricare Nepal Pvt. Ltd., available in liquid form, was prepared at a concentration of $3.3 \mathrm{ml} / 1000 \mathrm{ml}$ water. $20 \mathrm{~g}$ sugar was added as a nutrient, and 3 drops of Tween- 80 were added as an emulsifier.

(iii) Varunastra, manufactured by International Panaacea Ltd., India, available in liquid form, was prepared at a concentration of $6 \mathrm{ml} / 1000 \mathrm{ml}$ water, and 3 drops of Tween-80 were added as a surfactant.

(iv) Mahastra, manufactured by International Panaacea Ltd., available as a powder formulation, was prepared at the concentration of $6 \mathrm{~g} / 1000 \mathrm{ml}$ water.

(v) Neemraj Super, manufactured by Khadkeshwar Oil Mills Pvt. Ltd. and marketed by Neem India Products Pvt. Ltd., available in liquid form, was prepared at a concentration of $3.3 \mathrm{ml} / 1000$ water.

(vi) Tracer, manufactured by Dow Agro-Sciences India Pvt. Ltd., available in viscous form, was prepared at the concentration of $0.33 \mathrm{ml} / 1000 \mathrm{ml}$ water.

(vii) Pure water was used as the control treatment.

2.2. Bioassays. Fresh, uninfected rapeseed mustard twigs and wheat ears collected from the IAAS farm were washed thoroughly, dipped in a $1 \%$ sodium hypochlorite $(\mathrm{NaOCl})$ solution for 30 seconds, rinsed in distilled water, and airdried before treatment. Sterilized Petri dishes were provided with a moistened Whatman filter paper to maintain the humidity and hydrate the leaves. One mustard twig or wheat ear was used per Petri dish.

Two methods were used for evaluation of the efficacy of the treatments studied. 
TABle 1: Treatment details.

\begin{tabular}{|c|c|c|c|c|}
\hline Trade name & $\begin{array}{l}\text { Chemical/scientific } \\
\text { name }\end{array}$ & Dose & Manufacturer & Formulation \\
\hline $\begin{array}{l}\text { Biocide } \\
\text { Manic }\end{array}$ & M. anisopliae & $3 \mathrm{ml} / \mathrm{l}$ water & Agricare Nepal Pvt. Ltd. & M. anisopliae (a.i.) $=1 \times 10^{9}$ spores $/ \mathrm{ml}$ \\
\hline Agri Shakti & B. bassiana & $\begin{array}{l}3.3 \mathrm{ml} / \mathrm{l} \\
\text { water }\end{array}$ & Agricare Nepal Pvt. Ltd. & B. bassiana $=1 \times 10^{9}$ spores $/ \mathrm{ml}$ \\
\hline Varunastra & V. lecanii & $6 \mathrm{ml} / \mathrm{l}$ water & International Panaacea Ltd. & $\begin{array}{l}\text { V. lecanii spores }=2 \% \text { aqueous suspension, } \\
\qquad 2 \times 10^{8} \mathrm{CFU} / \mathrm{ml}\end{array}$ \\
\hline Mahastra & $\begin{array}{l}\text { B. thuringiensis var. } \\
\text { kurstaki }\end{array}$ & $6 \mathrm{~g} / \mathrm{l}$ water & International Panaacea Ltd. & $\begin{array}{c}\text { Delta endotoxin of } B \text {. thuringiensis var. kurstaki, } \\
0.5 \% \text { W.P. }\end{array}$ \\
\hline $\begin{array}{l}\text { Neemraj } \\
\text { Super }\end{array}$ & Azadirachtin & $\begin{array}{c}3.3 \mathrm{ml} / 1 \\
\text { water }\end{array}$ & $\begin{array}{l}\text { Khadkeshwar oil Mills Pvt. } \\
\text { Ltd. }\end{array}$ & Azadirachtin (a.i.) (min) $0.3 \% \mathrm{w} / \mathrm{w}$ \\
\hline Tracer & Spinosad & $\begin{array}{l}0.33 \mathrm{ml} / \mathrm{l} \\
\text { water }\end{array}$ & $\begin{array}{l}\text { Dow Agro-Sciences India } \\
\text { Pvt. Ltd. }\end{array}$ & $90 \%$ spinosyns \\
\hline Control & & Pure water & & \\
\hline
\end{tabular}

2.2.1. Leaf Dip Method. Sterilized mustard twigs or wheat ears were dipped into the appropriate biocide suspensions for 30 seconds and placed into Petri dishes. The treated twigs and ears were air-dried before fifty adult aphids were released into each Petri dish.

2.2.2. Leaf Spray Method. Sterilized mustard twigs or wheat ears were placed into Petri dishes with moistened Whatman filter papers. Fifty adult aphids were released to each dish. Treatments were then sprayed directly into the dishes.

Each treatment was replicated four times, and the experimental units were arranged in a randomized complete block design. Mortality assessment of aphids was based on visual inspection (movement of body parts and change in body colour of the aphids). Assessments were done 24, 48, 72 , and 98 hours after the treatment was applied.

2.3. Statistical Analysis. The experimental data were processed by using Excel 2007 and analyzed by using Agricolae package of RStudio 3.5.0. Mortality data of aphids were arcsine transformed, and pairwise comparison of means was carried out with Duncan's multiple range test (DMRT) at 5\% level [40].

\section{Results}

In the leaf spray bioassays with mustard aphids, the results revealed that the mortality caused by Agri Sakti was the greatest among all treatments at 24 hours after treatment (HAT) $\left(M=29.17 \pm 1.59 ; F_{3,6}=18.25 ; p<0.001\right)$. However Neemraj Super killed more aphids than did other treatments at $48 \operatorname{HAT}\left(M=48.33 \pm 2.89 ; F_{3,6}=22.75 ; p<0.001\right), 72$ HAT $\left(M=66.67 \pm 3.04 ; F_{3,6}=32.71 ; p<0.001\right)$, and $96 \mathrm{HAT}$ $\left(M=81.67 \pm 3.19 ; F_{3,6}=36.14 ; p<0.001\right)$. With the leaf dip method against mustard aphids, the mortality caused by Neemraj Super at 24 hours after release of aphids (HAR) $\left(M=31.67 \pm 2.89 ; \quad F_{3,6}=34.57 ; \quad p<0.001\right), \quad 48 \quad$ HAR $\left(M=52.50 \pm 2.50 ; \quad F_{3,6}=36.95 ; \quad p<0.001\right), \quad 72 \quad$ HAR $\left(M=68.33 \pm 3.97 ; \quad F_{3,6}=24.14 ; \quad p<0.001\right)$, and $96 \mathrm{HAR}$ $\left(M=78.33 \pm 3.97 ; F_{3,6}=23.07 ; p<0.001\right)$ showed it to be the most effective treatment at all time points. The effect of treatments with biorational compounds by both methods on mortality of mustard aphids was highly significant over control at all time points (Table 2).

In tests against English grain aphids using the leaf spray method, Agri Shakti was the most effective at all time points (24 HAT: $M=41.67 \pm 0.96 ; F_{3,6}=370.19 ; p<0.001 ; 48$ HAT: $M=73.33 \pm 1.36 ; \quad F_{3,6}=169.38 ; \quad p<0.001 ; 72 \quad$ HAT: $M=91.67 \pm 0.96 ; \quad F_{3,6}=278.91 ; \quad p<0.001 ; 96 \quad$ HAT: $\left.M=99.17 \pm 0.83 ; F_{3,6}=262.31 ; p<0.001\right)$. Likewise, using the leaf dip method against English grain aphids, Agri Shakti was the most effective treatment at all time points $24 \mathrm{HAR}$ $(41.67 \pm 0.96) \quad\left(F_{3,6}=370.19 ; \quad p \leq 0.001\right), \quad 48 \quad$ HAR $(66.67 \pm 1.36) \quad\left(F_{3,6}=169.38 ; \quad p \leq 0.001\right), \quad 72 \quad$ HAR $(85.00 \pm 0.96) \quad\left(F_{3,6}=278.91 ; p \leq 0.001\right)$, and $96 \mathrm{HAR}$ $(98.33 \pm 0.96)\left(F_{3,6}=262.31 ; p \leq 0.001\right)$ (Table 3$)$.

\section{Discussion}

The results of this study revealed that the mortality of both aphid species was consistently higher following treatment with biorational compounds than in the untreated control group. Application of Neemraj Super in both the leaf spray and leaf dip assays achieved the highest mortality of mustard aphids. A similar result was observed by Jahan [41] who reported that treating twigs with neem leaf extracts for $96 \mathrm{~h}$ resulted in a $50.58 \%$ reduction in the aphid population. Pandey et al. [42] reported that neem oil was $1.5 \%$ effective against L. erysimi under laboratory conditions, which is in line with our present results. Similarly, other studies have proved azadirachtin to be effective for managing the $L$. erysimi population $[43,44]$. Lowery and Isman [26] reported that crude formulations of neem seed extracts contain limonoids, a class of tetranortriterpenes with repellent and antifeedant modes of action [45]. In addition, azadirachtin has a strong negative influence on the behaviour, postembryonic development, and fecundity, contributing to its insecticidal properties [46]. The growth and development of aphids is inhibited due to a disbalance in hormonal regulation and the failure of growth of the reproductive organ [47]. Moreover, azadirachtin is known to affect more than 400 insect species belonging to the orders Diptera, Hymenoptera, Coleoptera, Lepidoptera, Orthoptera, Homoptera, 


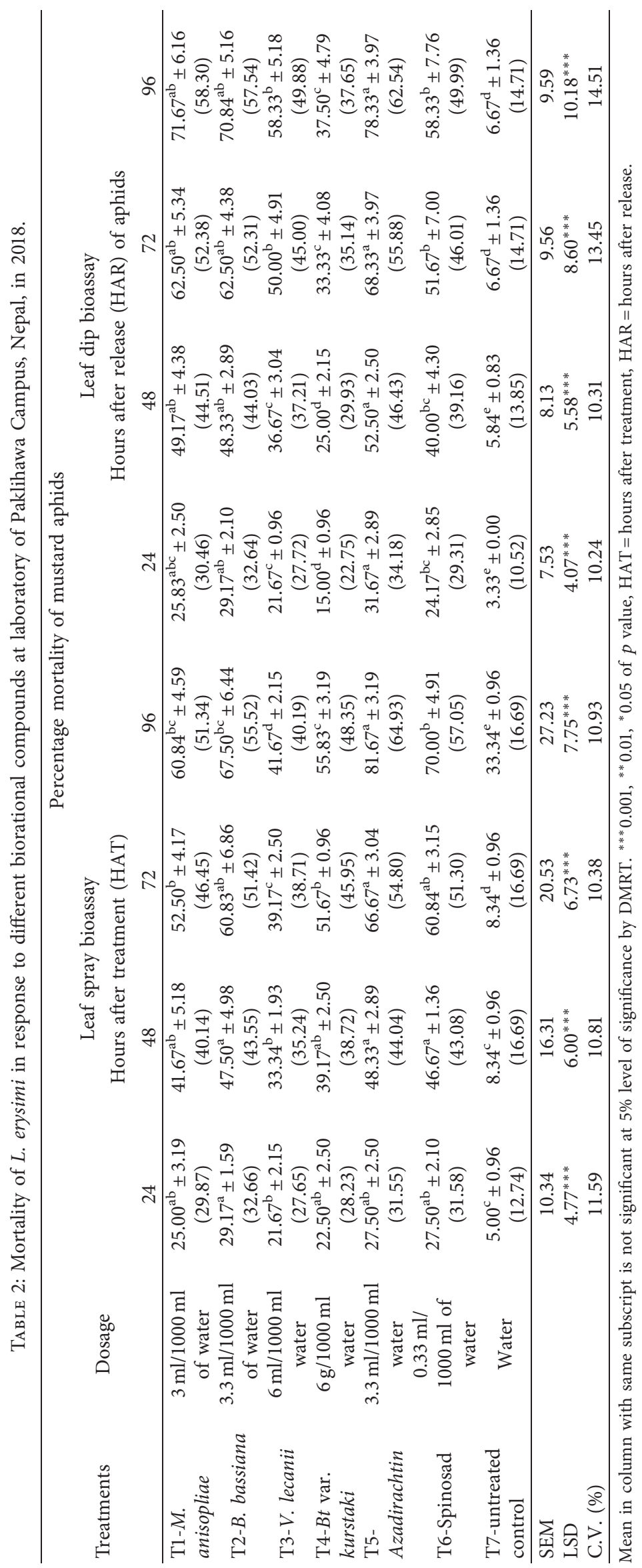




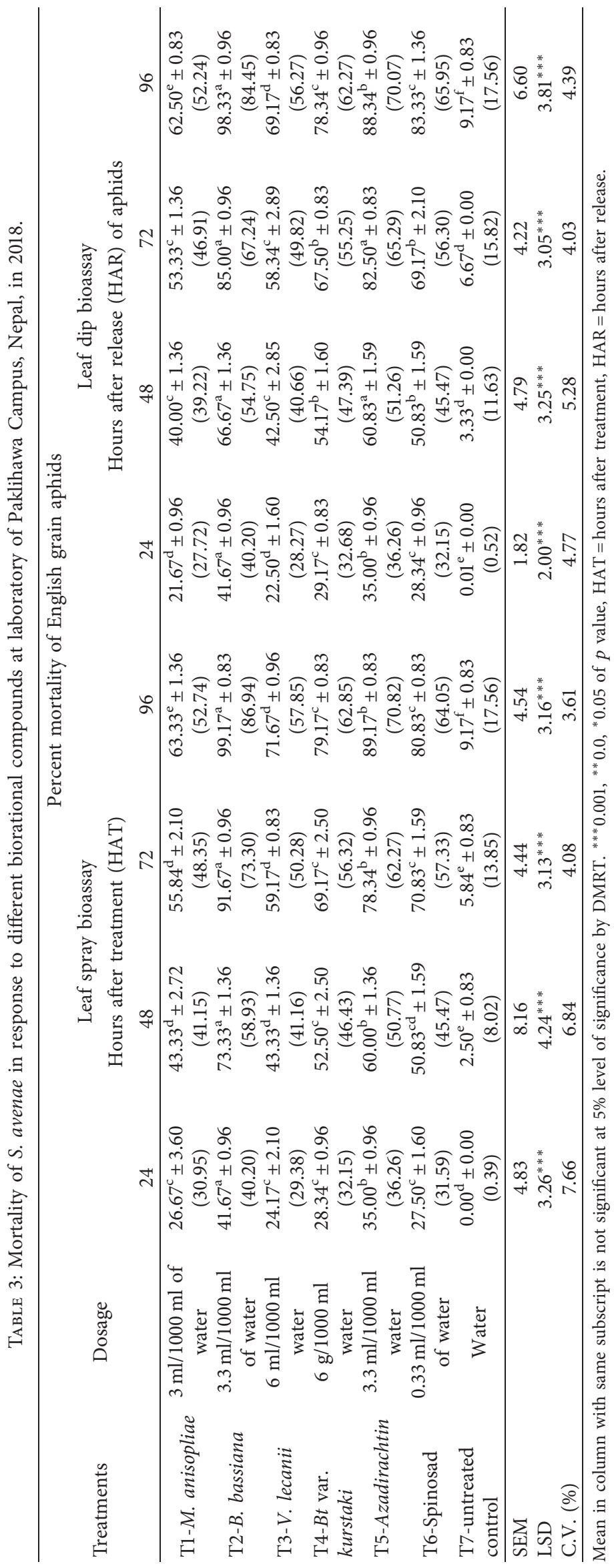


and Hemiptera but is usually safe for beneficial organisms such as bees, predators and parasitoids, and mammals and for the environment [48].

In addition to Neemraj Super, Agri Sakti was found to be the most effective biorational compound against the English grain aphid, both in spray and dip bioassays. This result is in line with the findings of Fang et al. [49]; who recorded a significant decrease in the aphid population by the application of the fungal entomopathogen B. bassiana. Many studies have shown the effectiveness of $B$. bassiana for controlling English grain aphid [50-52]. According to Fang et al. [49], B. bassiana was associated with higher aphid mortality rates due to mycosis by secreting specific hydrolytic enzymes that degrade the insect's cuticle, such as proteinase, chitinase, and lipase.

\section{Conclusion}

At all the observed time points, the mortality of mustard aphids and English grain aphids was significantly higher following the treatment with each biorational compound compared with the control. All biorational products used in the research could be good alternatives to chemical pesticides for the management of mustard and wheat aphids. They are safer, more environmentally sound, and more economically viable than their chemical counterparts. The spray method was found to be superior to the dipping method. Further studies are necessary to evaluate the efficacy of these biorational compounds infield conditions before they can be recommended as novel aphid management techniques.

\section{Data Availability}

The data used to support the findings of this study are available from the corresponding author upon written request.

\section{Conflicts of Interest}

The authors declare that there are no conflicts of interest regarding the publication of this paper.

\section{Acknowledgments}

The authors acknowledge the Institute of Agriculture and Animal Science, Paklihawa Campus, Nepal, for providing technical and financial support for this study.

\section{References}

[1] NORP, "National oilseed research program. Annual report. Varietal improvement on mustard," Nawalpur, Sarlahi, Nepal, 2011.

[2] T. B. Ghimire, R. N. Chaudhary, and S. P. Ray, "Quantification of yield limiting constraints in toria production," Annual report, NORP, 2000/2001, 2000.

[3] L. P. Amgain and J. Timsina, "Major agronomical research works at the Institute of Agriculture and Animal Sciences, Rampur, Chitwan, Nepal: a review," Journal of the Institute of Agriculture and Animal Science, vol. 26, pp. 1-20, 2005.
[4] S. R. Aryal, Statistical Year Book of Nepal Central Beauro of Statistics, National Planning Commission, Government of Nepal, Ramshahapath, Kathmandu, Nepal, 2017.

[5] N. K. Chaudhary, R. C. Sharma, N. K. Mishra, and K. R. Dahal, "Weed and fertilizer management in rapeseed and mustard," IAAS Research Reports (1985-1991), Institute of Agriculture and Animal Science, Rampur, Chitwan, Nepal, 1993.

[6] G. C. Sachan and J. P. Purwar, "Integrated insect management in rapeseed and mustard," in Entomology Novel Approaches, P. C. Jain and M. C. Bhargava, Eds., New India Publishing Agency, New Delhi, India, 2007.

[7] D. Raj and G. C. Lakhanpal, "Prevalence and impact of entomogenous fungus, Entomophthoraaphidis Hoffmann on three important aphid species infesting rapeseed in the Palam Valley of Himachal Pradesh (India)," Journal of Entomological Research, vol. 9, pp. 73-76, 1998.

[8] D. R. C. Bakhetia and B. S. Sekhon, "Insect-pests and their management in rapeseed-mustard," Journal of Oilseeds Research, vol. 6, pp. 269-299, 1989.

[9] H. R. Rohilla, H. Singh, V. K. Kalra, and S. S. Kharub, "Losses caused by mustard aphid, Lipaphis erysimi (Kalt.) in different Brassica genotypes," Proceedings of the International Rapeseed Congress, vol. 7, pp. 1077-1084, 1987.

[10] J. S. Rana, "Performance of Lipaphis erysimi (Homoptera: Aphididae) on different Brassica species in a tropical environment," Journal of Pest Science, vol. 78, no. 3, pp. 155-160, 2005.

[11] S. Pradhan, M. G. Jotwani, and P. Sarup, "Control schedule of mustard crop, particularly against mustard aphid," Indian Oilseed Journal, no. 4, pp. 125-141, 1960.

[12] C. P. Singh and G. C. Sachan, "Ecofriendly management of Lipaphiserysimi (Kalt.) in Brassica carinata," in Proceedings of the 10th International Rapeseed Congress, N. Wratten and P. A. Salisbury, Eds., pp. 26-29, The Regional Institute Ltd, Canberra, Australia, 1999.

[13] R. L. Metcalf, Destructive and Useful Insects Their Habits and Control, McGraw-Hill Book Company, New York, NY, USA, 1962.

[14] S. R. Singh, A. Narain, K. P. Srivastava, and J. A. Siddiqui, "Fecundity of mustard aphid of different rapes and mustard species," Indian Oilseeds Journal, vol. 9, no. 3, pp. 215-219, 1965.

[15] S. A. P. Santos, C. Santos, S. Silva, G. Pinto, L. M. Torres, and A. J. A. Nogueira, "The effect of sooty mold on fluorescence and gas exchange properties of olive tree," Turkish Journal of Biology, vol. 37, no. 5, pp. 620-628, 2013.

[16] K. Kafle, "Management of mustard aphid Lipaphis erysimi (Kalt.) (Homoptera: Aphididae)," International Journal of Applied Sciences and Biotechnology, vol. 3, no. 3, pp. 537-540, 2015.

[17] W. Kolbe and W. Linke, "Studies of cereal aphids; their occurrence, effect on yield in relation to density levels and their control," Annals of Applied Biology, vol. 77, no. 1, pp. 85-87, 1974.

[18] W. F. Tjallingii, "Salivary secretions by aphids interacting with proteins of phloem wound responses," Journal of Experimental Botany, vol. 57, no. 4, pp. 739-745, 2006.

[19] L. S. Brooks, G. Amosson, G. Hein et al., Economic Impact of the Russian Wheat Aphid in the Western United States: 1990-1992, Great Plains Agricultural Council Publication, GPAC-143, Denver, CO, USA, 1994. 
[20] J. P. Michaud and P. E. Sloderbeck, Russian Wheat Aphid, Kansas State University, Manhattan, KS, USA, 2005, http:// www.oznet.ksu.edu/library/entml2/mf2666.pdf.

[21] X.-F. Liu, X.-S. Hu, M. A. Keller, H.-Y. Zhao, Y.-F. Wu, and T.-X. Liu, "Tripartite interactions of barley yellow dwarf virus, Sitobion avenae and wheat varieties," PLoS One, vol. 9, no. 9, Article ID e106639, 2014.

[22] J. A. Webster, R. L. Burton, and K. J. Starks, "Diuraphis noxia, a new aphid pest of small grains," Journal of the Kansas Entomological Society, vol. 60, no. 3, p. 483, 1987.

[23] M. Hussain, "Controlling rice borer under Bangladesh conditions," Pestology, vol. 8, p. 28, 1989.

[24] A. L. Devonshire, L. M. Field, S. P. Foster, G. D. Moores, M. S. Williamson, and R. L. Blackman, "The evolution of insecticide resistance in the peach-potato aphid, Myzus persicae," Philosophical Transactions of the Royal Society of London. Series B: Biological Sciences, vol. 353, no. 1376, pp. 1677-1684, 1998.

[25] S. P. Foster, R. Harrington, A. M. Dewar, I. Denholm, and A. L. Devonshire, "Temporal and spatial dynamics of insecticide resistance in Myzus persicae (Hemiptera: Aphididae)," Pest Management Science, vol. 58, no. 9, pp. 895-907, 2002.

[26] D. T. Lowery and M. B. Isman, "Insect growth regulating effects of neem extract and azadirachtin on aphids," Entomologia Experimentalis et Applicata, vol. 72, no. 1, pp. 77-84, 1994.

[27] J. Harris and D. R. Dent, Priorities in Biopesticide Research and Development in Developing Countries, CABI, Wallingford, UK, 2000.

[28] E. Yano, "Ecological considerations for biological control of aphids in protected culture," Population Ecology, vol. 48, no. 4, pp. 333-339, 2006.

[29] F. M. Fishel, Pesticide Effects on Nontarget Organisms Pesticides Information Office, Institute of Food and Agricultural Sciences, University of Florida, Gainesville, FL, USA, 2005.

[30] W. Aktar, D. Sengupta, and A. Chowdhury, "Impact of pesticides use in agriculture: their benefits and hazards," Interdisciplinary Toxicology, vol. 2, no. 1, pp. 1-12, 2009.

[31] M. J. Bidochka, A. M. Kamp, and J. A. De Croos, "Insect pathogenic fungi: from genes to populations," in Fungal Pathology, Springer, Berlin, Germany, 2000.

[32] M. I. Dar, I. D. Green, M. I. Naikoo, F. A. Khan, A. A. Ansari, and M. I. Lone, "Assessment of biotransfer and bioaccumulation of cadmium, lead and zinc from fly ash amended soil in mustard-aphid-beetle food chain," Science of the Total Environment, vol. 584-585, pp. 1221-1229, 2017.

[33] S. B. Alves, L. S. Rossi, R. B. Lopes, M. A. Tamai, and R. M. Pereira, "Beauveria bassiana yeast phase on agar medium and its pathogenicity against Diatraea saccharalis (Lepidoptera: Crambidae) and Tetranychus urticae (Acari: Tetranychidae)," Journal of Invertebrate Pathology, vol. 81, no. 2, pp. 70-77, 2002.

[34] E. Klinger, E. Groden, and F. Drummond, "Beauveria bassiana horizontal infection between cadavers and adults of the Colorado potato beetle, Leptinotarsa decemlineata(Say)," Environmental Entomology, vol. 35, no. 4, pp. 992-1000, 2006.

[35] M. A. Aqueel and S. R. Leather, "Virulence of Verticillium lecanii (Z.) against cereal aphids; does timing of infection affect the performance of parasitoids and predators?" Pest Management Science, vol. 69, no. 4, pp. 493-498, 2013.

[36] T. R. Glare and M. O Callaghan, Bacillus thuringiensis: Biology, Ecology and Safety, John Wiley, Chichester, NY, USA, 2000 .
[37] R. C. Saxena, "Insecticides from neem," in Insecticides of Plant Origin (ACS Symposium Series 3), J. T. Arnason and P. Morand, Eds., pp. 110-135, American Chemical Society, Washington, DC, USA, 1989.

[38] M. R. d. Faria and S. P. Wraight, "Mycoinsecticides and mycoacaricides: a comprehensive list with worldwide coverage and international classification of formulation types," Biological Control, vol. 43, no. 3, pp. 237-256, 2007.

[39] L. G. Copping, The Manual of Biocontrol Agents, British Crop Protection Council, Hampshire, UK, 2004.

[40] K. Gomez and A. A. Gomez, Statistical Procedures for Agricultural Research, John Wiley and Sons Inc, New York, NY, USA, 2nd edition, 1984.

[41] R. Jahan, M. M. Uddin, M. M. Rahman, and M. A. Haque, "Varietal preference and management of bean aphid, Aphis craccivora (Koch)," Persian Gulf Crop Protection, vol. 2, no. 3, pp. 40-46, 2013.

[42] N. D. Pandey, Y. P. Singh, and R. A. Tripathi, "Effect of certain plant extracts against Lipaphis erysimi under laboratory conditions," Indian Journal of Entomology, vol. 49, no. 2, pp. 238-242, 1987.

[43] G. Biswas, "Comparative effectiveness of neem extracts and synthetic organic insecticide against mustard aphid," Bangladesh Journal of Agricultural Research, vol. 38, no. 2, pp. 181-187, 2013.

[44] A. Ali, P. Rizvi, and F. Khan, "Bio-efficacy of some plant leaf extracts against mustard aphid, Lipaphis erysimi Kalt. On Indian mustard, Brassica juncea," Journal of Plant Protection Research, vol. 50, no. 2, 2010.

[45] S. Himesh, K. Mishra, S. Sharma, and A. K. Singhai, "Characterization of Azadirachtin from ethanolic extract of leaves of Azadirachtaindica," Journal of Pharmacy Research, vol. 5, no. 1, pp. 199-201, 2011.

[46] H. E. Hummel, D. F. Hein, and H. Schmutterer, "The coming of age of azadirachtins and related tetranortriterpenoids," Journal of Biopesticides, vol. 5, pp. 82-87, 2012.

[47] O. M. L. Lynn, S. Woo-Geun, S. Jae-Kyoung, K. Jang-Eok, and L. Kyeong-Yeoll, "Effects of azadirachtin and neem-based formulations for the control of sweetpotato whitefly and rootknot nematode," Journal of the Korean Society for Applied Biological Chemistry, vol. 53, no. 5, pp. 598-604, 2010.

[48] Y. Q. Tang, A. A. Weathersbee III, and R. T. Mayer, "Effect of neem seed extract on the brown citrus aphid (Homoptera: Aphididae) and its parasitoid Lysiphlebus testaceipes (Hymenoptera: Aphidiidae)," Environmental Entomology, vol. 31, no. 1, pp. 172-176, 2002.

[49] M.-G. Fang, J. B. Johnson, and L. P. Kish, "Virulence of Verticillium lecanii and an aphid-derived isolate of Beauveria bassiana (fungi: Hyphomycetes) for six species of cerealinfesting aphids (Homoptera: Aphididae)," Environmental Entomology, vol. 19, no. 3, pp. 815-820, 1990.

[50] G. R. Knudsen, D. J. Schotzko, and C. R. Krag, "Fungal entomopathogen effect on numbers and spatial patterns of the Russian wheat aphid (Homoptera: Aphididae) on preferred and nonpreferred host plants," Environmental Entomology, vol. 23, no. 6, pp. 1558-1567, 1994.

[51] J. D. Vandenberg, L. E. Sandvot, S. T. Jaronski, M. A. Jackson, and S. E. Halberts, "Efficacy of fungi for control of Russian wheat aphid (Homoptera: Aphididae) in irrigated wheat," Southwestern Entomologist, vol. 26, no. 1, pp. 73-85, 2001.

[52] L. H. Justin, P. Stephen, and R. M. Miller, "Efficacy of Beauveria bassiana for control of russian wheat aphid (Homoptera: Aphididae) on resistant wheat under field condition," pp. 455-473, 2003. 